\title{
Strategi Peningkatan Penjualan Makanan Tradisional Sunda Melalui Daya Tarik Produk Wisata Kuliner di The Jayakarta Bandung Suite Hotel \& Spa
}

\author{
Ilham Fajri \\ Akademi Pariwisata NHI \\ Ilhamfajri203@gmail.com
}

\begin{abstract}
The increase in the number of visitors to the hotel each year has the potential to further develop, but the problem is the appeal of Traditional Sundanese Foods found in the hotel is not known by many people. This study aims to formulate the appropriate sales promotion strategy to be applied at The Jayakarta Bandung Suite Hotel \& Spa through SWOT analysis approach. Where based on SWOT analysis results, external factors with the highest score that affect the increase in sales is an opportunity factor is branding the city of Bandung as a culinary destination, while the highest threat is food from other countries. Internal factor with highest score is the strength factor that is the appeal of the menu offered, while the weakness factor is promotion. A suitable strategy to be applied for market is penetration strategy and product improvement strategy.
\end{abstract}

Keywords - swot analysis; culinary tour; traditional sundanese food

Abstrak-Peningkatan jumlah pengunjung Hotel tiap tahun berpotensi untuk lebih berkembang, namun masalahnya daya tarik Makanan Tradisional Sunda yang terdapat di hotel tersebut belum diketahui oleh banyak orang. Penelitian ini bertujuan untuk memformulasikan strategi peningkatan penjualan yang tepat untuk diterapkan di The Jayakarta Bandung Suite Hotel \& Spa melalui pendekatan analisis SWOT. Dimana berdasarkan hasil analisis SWOT, faktor eksternal dengan skor tertinggi yang mempengaruhi peningkatan penjualan adalah faktor peluang yaitu branding kota Bandung sebagai tujuan wisata kuliner, sedangkan ancaman tertinggi adalah makanan dari negara lain. Faktor internal dengan skor tertinggi adalah faktor kekuatan yaitu daya tarik menu yang ditawarkan, sedangkan faktor kelemahan yaitu promosi. Strategi yang cocok diterapkan adalah strategi penetrasi pasar dan strategi peningkatan produk.

Kata kunci-analisis swot; wisata kuliner; makanan tradisional sunda

\section{PENDAhuluan}

Seiring dengan meningkatnya kompetisi pada Hotel dan berkembangnya industri pariwisata di Bandung, kebudayaan lokal menjadi suatu hal yang berharga untuk menarik wisatawan baik dalam produk maupun aktivitasnya. Termasuk wisata kuliner yang merupakan salah satu budaya lokal yang juga bisa menjadi usaha kepariwisataan sesuai dengan UUD RI No.10 Thn.2009 pasal 14 Ayat 1 tentang usaha pariwisata. Dapat dikatakan wisata kuliner timbul dari minat para wisatawan yang meninginkan pengalaman wisata, selain dari keelokan alamnya akan tetapi juga dari makanan atau kuliner tradisional yang disajikan.

Salah satu makanan tradisional yang memiliki keunikan tersendiri dari makanan tradisional Indonesia lainnya adalah makanan tradisional Sunda. Makanan tradisional sunda merupakan makanan yang paling terkenal di Indonesia. Makanan tradisional Sunda ini mempunyai ke khasan pada kesegaran bahan- nya, serta lalapanya yang biasa dikonsumsi secara langsung dengan dicampur bumbu dan sambal yang khas seperti karedok, memperlihatkan bahwa orang Sunda sangat gemar pada sayur-sayuran mentah yang segar. Ciri khas lain dari masakan tradisional Sunda yaitu dapat menggunakan bahan-bahan dasar dimana rata-rata orang menganggap bahan tersebut tidak dapat dimanfaatkan. Misalkan seperti tumis genjer, goreng impun yang dibuat dari anak ikan yang terdapat di sungai liar, sayur kadedemes yang seringkali dianggap tidak layak dimakan, hama keong atau tutut, yang hidup di pesawahan. Kemudian sambal goreng ati sapi atau jeroan sapi. Juga masakan cumi kuah hitam, dimana warna hitam kuahnya berasal dari cumi nya langsung yang sengaja dipakai.

Sesuai dengan keinginan pemerintah yang dituangkan melalui Peraturan presiden No. 22 thn 2009 tentang kebijakan pengangkatan keanekaragaman konsumsi pangan berbasis sumber daya lokal, dimana Departemen 
Pariwisata dan Kebudayaan merupakan salah satu instansi lembaga yang memberikan dukungan ini meminta kepada hotel untuk menyajikan makanan nusantara atau olahan pangan lokal kepada para pelanggan.

Salah satu hotel bintang 4 yaitu The Jayakarta Bandung Suite Hotel \& Spa, mencoba menawarkan menu makanan khas Sunda dan aneka jajanan khas sunda pada saat Breakfast. Hal ini didasarkan juga dengan PerDa Kota Bandung No. 05 Thn 2012 Tentang Pelestarian Seni Tradisional Pasal 24 dan 25. Ada banyak macam aneka jajanan tradisional Sunda yang disuguhi kepada pengunjung di Hotel tersebut. Akan tetapi menu makanan tradisional sunda yang di sajikan di The Jayakarta Bandung Suite Hotel \& Spa mengalami tidak adanya peningkatan pada penjualannya atau bahkan menurun, sehingga Hotel tersebut hanya menyediakan beberapa jenis masakan tradisional sunda seperti Sop Buntut, Nasi Timbel dan Soto Bandung dalam menunya.

Dalam merumuskan perencanaan jangka panjang, strategi peningkatan penjualan merupakan cara di dalam proses penjualan yang dapat memberikan efek peningkatan pada nilai penjualan. Strategi penjualan yang unik dan kreatif akan menjadikan para konsumen lebih tertarik dibandingkan dengan cara-cara monoton yang sudah biasa dilakukan orang. Dengan adanya strategi peningkatan penjualan yang baik dan jelas, maka dapat dilihat tingkat penjualan yang meningkat pada saat proses evaluasi. Untuk melihat strategi yang tepat dalam meningkatkan penjualan maka perencanaan strategi adalah proses yang tepat dengan menggunakan analisis lingkungan, baik itu lingkungan eksternalnya maupun lingkungan internal. Melalui perencanaan ini pula, sasaran dan tujuan perusahaan akan dapat tercapai. Maka berdasarkan hal tersebut, sangat perlu dilakukan penelitian tentang "Strategi Peningkatan Penjualan Makanan Tradisional Sunda Melalui Daya Tarik Produk Wisata Kuliner di The Jayakarta Bandung Suite Hotel \& Spa".

\section{A. Rumusan Masalah}

Melihat latar belakang dari penelitian di atas, yang menjadi inti permasalahan dalam penelitian ini yaitu strategi apa yang tepat dalam meningkatkan penjualan makanan tradisional Sunda di The Jayakarta Bandung Suite Hotel \& Spa. Atas hal ini untuk lebih jelasnya data rumusan masalah penelitian ini bisa dilihat pada pertanyaan penelitian berikut.

\section{B. Tujuan Penelitian}

Penelitian ini secara umum bertujuan untuk mengetahui sejauh mana pihak hotel meningkatkan penjualan makanan tradisional Sunda di hotel The Jayakarta Bandung Suite Hotel \& Spa. Sedangkan secara khususnya memiliki tujuan untuk :

1. Menganalisis lingkungan eksternal dan internal strategi peningkatan penjualan makanan tradisional Sunda meliputi bahan makanan, peralatan, dan cara penyajian di The Jayakarta Bandung Suite Hotel \& Spa .

2. Menganalisis aspek apa saja dalam daya tarik produk wisata kuliner yang dapat digunakan sebagai strategi dalam peningkatan penjualan makanan tradisional Sunda di The Jayakarta Bandung Suite Hotel \& Spa.

3. Menentukan strategi apa yang dapat diaplikasikan dalam meningkatkan penjualan makanan tradisional Sunda di The Jayakarta Bandung Suite Hotel \& Spa.

\section{Manfaat Penelitian}

Penelitian ini secara teoritis diharapkan bisa dapat digunakan untuk kepentingan akademis dalam bidang ilmu pengetahuan terutama di bidang ilmu Manajemen perhotelan dalam Strategi Peningkatan Penjualan Produk makanan tradisionalnya selain penjualan kamar, sekaligus juga dapat menjadi bahan acuan pemikiran bagi para peneliti kedepannya dalam melakukan penelitian yang hampir sama dengan penelitian ini. Sedangkan Manfaat praktisnya ialah :

1. Dapat dijadikan acuan pemerintah dalam langkah pengambilan kebijakan terhadap pengangkatan makanan tradisional sunda di restaurant hotel.

2. Memberikan informasi dan sumbangan pemikiran kepada para pelaku pariwisata, baik itu pemilik rumah makan atau restoran, serta masyarakat setempat mengenai kekuatan dan kelemahan juga peluang serta ancaman, dari faktor internal dan eksternal yang berkaitan dengan peningkatan penjualan makanan tradisional Sunda.

\section{KAJIAN PUSTAKA}

\section{A. Konsep Strategi}

Menurut Stoner (Tjiptono, 2011 : 3) menyatakan bahwa terdapat dua perspektif yang berbeda dalam strategi, yaitu perspektif kepada apa yang ingin dijalankan oleh organisasi (intend to do) dan apa yang akhirnya dijalankan oleh organisasi (eventually does). Berdasarkan dari perspektif pertama, strategi dapat didefinisikan sebagai program untuk menentukan dan mencapai tujuan organisasi dalam menjalankan rencananya. Makna yang didapat dari strategi ini adalah dalam 
merumuskan strategi organisasi para manager memainkan peran yang aktif secara sadar dan rasional. Kemudian pada perspektif yang kedua, strategi didefinisikan sebagai pola respon atau tanggapan organisasi terhadap lingkungannya. Setiap organisasi pasti memiliki strategi, meskipun strategi tersebut tidak pernah dirumuskan secara eksplisit. Pandangan ini diterapkan bagi para manager yang memiliki sifat reaktif, artinya dapat menyesuaikan diri dan tanggap terhadap lingkungan secara pasif.

\section{B. Peningkatan Penjualan}

Dalam Ensiklopedi (duniapelajar.com) Peningkatan adalah asal kata dari kata tingkat yang berarti deretan dari sesuatu yang kemudian membentuk sebuah susunan. Kata peningkatan meng-gambarkan perubahan dari keadaan atau sifat yang negatif berubah menjadi positif. Sedangkan Penjualan (Marom, 2002:28) adalah penawaran barang dagangan sebagai usaha pokok perusahaan yang biasanya dilakukan secara berkala.

Hasil penjualan yang terus naik meningkat merupakan tujuan dari konsep strategi peningkatan ini, maksudnya yaitu memperoleh laba dengan pemenuhan keinginan dan kebutuhan dari tamu. Dengan adanya laba yang didapat, maka perusahaan dapat terus meningkat dengan pengembangan kemampuan yang lebih besar, dengan kata lain perusahaan dapat memperkuat posisinya dalam menjalankan kelangsungan hidupnya. Sehingga lebih mudah dalam menyediakan barang dan jasa yang dapat memberikan tingkat kepuasan yang lebih besar kepada konsumen.

Basu Swastha (2001 : 22) untuk beberapa faktor yang mempengaruhi dalam peningkatan penjualan yaitu sebagai berikut :

1. Produk. Salah satu bagian dari penjualan adalah produk yang dijual, dimana penjual diminta untuk bertindak secara konstan dan inovatif dalam memproduksi produk serta memberikan saran perbaikan yang diperlukan dalam memproduksi /mengembangkan sebuah produk.

2. Harga Adalah jumlah nominal uang yang harus dibayarkan oleh konsumen dalam mendapatkan suatu produk yang diinginkan. Penetapan harga suatu produk merupakan salah satu usaha penjual untuk menarik para pembeli agar mau membeli produk yang dijual dalam jumlah yang banyak.

3. Distribusi. Merupakan jalur barang dari produsen ke konsumen. Semakin luas pendistribusian maka akan mempengaruhi penjualan
4. Promosi, yaitu aktifitas yang dijalankan perusahaan bertujuan membujuk, menginformasikan, mengingatkan dan mempengaruhi konsumen agar membeli produk yang ditawarkan.

C. Penerapan Strategi Peningkatan Penjualan Pada Hotel

Untuk mewujudkan sebuah strategi peningkatan penjualan menurut Yodhia Antariksa (rajapresentasi.com) didasarkan kepada faktor-faktor yang mempengaruhi penjualan (Basu Swastha, 2001 : 22) ada beberapa hal penting yang perlu diperhatikan terkait dengan strategi dalam peningkatan penjualan, yaitu:

1. Kualitas produk atau layanan jasa yang diberikan. Dalam merancang strategi penjualan, sebelumnya harus memastikan terlebih dahulu bahwa kualitas dari produk atau layanan jasa yang ditawarkan. Ini merupakan hal yang sangat penting yang akan dirasakan oleh konsumen pada saat akan membeli atau memakai layanan jasa. Jika produk yang ditawarkan atau layanan jasa yang diberikan kurang berkualitas, maka perusahaan harus memiliki keunggulan tertentu yang tidak didapati pada produk atau jasa yang ditawarkan pihak lain. Sehingga konsumen memiliki alasan yang kuat untuk tetap membeli produk atau layanan jasa yang ditawarkan.

2. Pelayanan dan Pendistribusian yang baik pada saat proses penjualan. Dalam menjalankan strategi peningkatan penjualan, satu hal yang perlu diingat adalah bahwa pembeli adalah raja. Artinya penjual harus memberikan pelayanan sebaik-baiknya terhadap para konsumen. Penjual perlu memperhatikan gaya bertutur kata, sikap, respon, cara menjawab pertanyaan konsumen dan sebagainya. Jangan sampai bersikap kasar pada pelanggan, atau berwajah angkuh kepada para konsumen, karena akan berdampak pada pencitraan bisnis yang di kelola. Di dalam hal ini, sangat penting menumbuhkan sikap sabar terhadap konsumen. Terkadang memang ada banyak hal yang membuat pihak pengelola bisnis menjadi terpancing emosi. Untuk hal ini memang diperlukan upaya pengelolaan emosional yang baik terutama untuk mereka yang bekerja sebagai penjual atau marketing.

3. Promosi dan promosi. Strategi peningkatan penjualan yang paling ampuh tak lain adalah upaya promosi yang maksimal. Sehebat apapun produk atau jasa layanan yang diberikan, jika tidak ada upaya promosi yang maksimal, maka angka penjualan 
perusahaan akan biasa saja. Namun sebaliknya, meskipun kualitas produk atau layanan perusahaan biasa saja, tapi promosi berjalan maksimal, maka hasilnya akan akan lebih berefek. Promosi sebagai bagian dari strategi peningkatan penjualan yang berguna untuk mengenalkan sebuah produk kepada konsumen, baik itu tentang bagaimana kualitasnya maupun cara penggunaannya.

\section{Makanan Tradisional Sunda}

Melihat pada Kamus Umum Bahasa Indonesia (2008:1543) kata makanan berartikan sesuatu hal yang dimasukkan ke dalam mulut yang padanya memiliki fungsi untuk memberikan nutrisi pada tubuh, sedangkan kata tradisional bermakna sebagai sesuatu yang memiliki sifat turun temurun baik itu suatu adat daerah atau kawasan. sehingga apabila ditarik kesimpulan dari makna diatas, maka makanan tradisional adalah segala sesuatu yang dikonsumsi oleh masyarakat suatu daerah tertentu yang dilakukan secara turun temurun guna memenuhi kebutuhan nutrisi bagi masyarakat.

Dalam Ensiklopedi Wikipedia, Masakan Sunda adalah salah satu makanan yang sangat terkenal di Indonesia yang mempunyai ciri khas tersendiri seperti karedok dengan lalap mentah yang biasa dimakan dengan campuran sambal kacang sehingga memperlihatkan bahwa orang Sunda sangat menggemari sayuran segar yang mentah. Lain halnya dengan masakan minangkabau yang padanya rata-rata banyak terdapat akan aneka bumbu, serta memiliki rasa yang pedas juga padanya terdapat banyak kandungan santan yang kental dan bumbu kari yang pekat. Dibandingkan dengan masakan minangkabau, masakan Sunda banyak menyajikan citarasa yang sederhana, jelas dan ringan, antara asam segar, gurih asin, pedas, dan manis ringan. Penyertaan bumbu yang paling sering digunakan dalam sajian masakan Sunda adalah Sambal terasi, dimakan disertai lalab juga tempe dan tahu yang di goreng.

\section{E. Makanan Sunda sebagai Daya Tarik Wisata Kuliner}

Daya tarik wisata kuliner dewasa ini berkembang sebagai suatu wujud penawaran akan pengalaman yang nyata. Dimana wisata kuliner diinterpretasikan sebagai bentuk wisata yang dinikmati oleh kelima panca indera manusia, yakni dengan dilihat, didengar, dicium, diraba dan dirasakan. Dimana kesemuanya itu berkembang dari satu titik awal yang disebut 'makanan'. Dalam hal ini, makanan dinilai sebagai budaya dalam pengalaman mengonsumsi, mempelajari dan pengetahuan tentang makanan, yang termasuk warisan/pusaka budaya tidak hanya yang berbentuk fisik (misalnya bangunan atau arsitektur bersejarah) dan unsur budaya atau seni (Sumaryadi \& Pah, 2010:477).

Menurut Sumaryadi \& Pah (2010:477) aspek dari makanan dan minuman itu meliputi bahan baku, cara pengolahan dan cara penyajiannya.

Bahan baku dinilai sebagai aspek daya tarik wisata kuliner, karena bahan baku mengidentifikasikan corak dan ragam makanan yang disajikan. Dimana dalam hal ini, bahan baku sangat tergantung pada keadaan alam dan pada pola hidup masyarakat. Masyarakat yang tinggal dalam lingkungan alam dengan curah hujan tinggi akan memiliki pola hidup menetap (sedenter) dengan sistem bercocok tanam sehingga bahan baku yang dimiliki akan semakin beragam dan hasil olahannya pun semakin kaya. Berbanding dengan masyarakat lain yang tinggal pada daerah padang rumput, steppa, daerah savanna dengan iklim cukup kering dan sistem hidup berpindah-pindah (nomaden) yang memiliki bahan baku yang terbatas. Sehingga Adimihardja (2005:4) mengemukakan bahwa perbedaan corak hidup antara masyarakat sedenter dan masyarakat nomaden akan berpengaruh dalam mengembangkan corak dan ragam dalam pola konsumsi.

Kemudian Pengolahan, sejak zaman abad sebelum masehi perkembangan pengolahan makanan sudah dimulai dimana dalam pengolahan makanannya menerapkan panas yang sederhana. Seiring berjalannya waktu perkembangan penyajian makanan dan teknik pengolahannya menjadikan adanya pemahaman-pemahaman baru dalam dunia gastronomi. Misalnya nouvele cuisine, classical cooking, moleculer, fusion food, sampai dengan yang dinamakan courtesy food gastronomie.

Lalu Penyajian dimana dalam daya tarik wisata kuliner penyajian menjadi sebuah aspek penting cara menyajikan suatu makanan yang menggambarkan kebisaan makan atau budaya makan. Dalam sebuah restoran maupun hotel, peran menyajikan makanan menjadi tugas dari seorang pramusaji.

\section{MetOde PENELITIAN}

\section{A. Jenis dan Metode Penelitian}

Metode penelitian yang digunakan dalam penelitian ini adalah Metode Penelitian Deskriptif, yaitu suatu metode dalam meneliti status suatu objek, sekelompok manusia, suatu sistem pemikiran, suatu set kondisi,ataupun suatu kelas peristiwa masa sekarang dengan membuat gambaran secara sistematis atau deskripsi, faktual dan akurat mengenai sifat-sifat 
atau fakta-fakta serta hubungan antar fenomena yang diselidiki dengan interpretasi yang tepat (Nazir, 2005:54).

\section{B. Sumber Informasi}

Sumber informasi yang penulis peroleh terbagi menjadi dua jenis sumber, yaitu :

1. Data primer, yaitu data yang didapatkan secara langsung dari responden penelitian yang terdiri atas kepala dapur hotel dan Manajer Hotel serta wisatawan yang berkunjung. Pengumpulan data dilakukan melalui daftar pertanyaan dan wawancara yang bertujuan untuk mengetahui pendapat responden mengenai semua hal tentang makanan tradisional sunda sebagai makanan yang dihidangkan kepada wisatawan.

2. Data sekunder, yaitu data yang didapatkan dari sumber-sumber lain, baik yang sudah diolah maupun belum, yang menunjang penelitian seperti profil tempat penelitian dan teori-teori dari berbagai pustaka yang digunakan sebagai landasan.

\section{Teknik dan Alat Pengumpulan Data}

Observasi, wawancara, dan dokumentasi adalah teknik pengumpulan data yang penulis gunakan, yaitu dengan mengobservasi, mewawancarai subjek, serta mendokumentasikan semua kegiatan yang berkaitan dengan potensi makanan tradisional Sunda yang dihidangkan kepada wisatawan yang berkunjung ke The Jayakarta Bandung Suite Hotel \& Spa.

1. Survei observasi (observational surveys) yaitu pengamatan secara langsung ke lokasi penelitian agar dapat melihat secara jelas mengenai gambaran umum lokasi penelitian mengenai prilaku dan aktivitas, serta lingkungannya. Hal ini sangat penting karena dilakukan dengan turun langsung ke lapangan, sehingga penulis bisa melihat kondisi lapangan dengan nyata.

2. Penyebaran angket (questionnaires) Kuesioner adalah suatu draf pertanyaan terstruktur secara tertulis yang sudah dirumuskan sebelumnya, yang kemudian dijawab oleh responden. Penyebaran angket kuesioner ini memiliki tujuan untuk mengetahui pendapat para wisatawan yang berkunjung ke hotel, juga para pengelola atau pemilik hotel mengenai potensi makanan tradisional Sunda berkaitan dengan faktor internal maupun eksternal yang disajikan kepada wisatawan yang berkunjung ke The Jayakarta Bandung Suite Hotel \& Spa.
3. Wawancara mendalam (indepth interview) Merupakan metode pengumpulan data dalam rangka memperoleh informasi melalui wawancara terhadap responden secara langsung. Metode ini dapat dilakukan secara terstruktur ataupun tidak terstruktur, tatap muka langsung, ataupun tidak langsung dengan melalui telepon ataupun online.

4. Studi dokumentasi (documentation studies) Merupakan teknik pengumpulan data dengan menelusuri dokumen-dokumen yang berkaitan dengan penelitian seperti monografi wilayah, brosur, dan termasuk pula pengambilan gambar sebagai bukti pelaksanaan penelitian.

\section{Teknik Analisis Data}

Dalam menganalisis, SWOT adalah alat yang penulis pakai, karena menurut Bozac dan Tipuric (dalam Hendrayana, 2011:51) untuk mengenali situasi analisis SWOT adalah alat yang tepat yang jika dijalankan dengan benar maka akan menghasilkan pondasi yang kuat dalam merumuskan atau memformulasikan suatu strategi. Analisis SWOT juga digunakan sebagai alat untuk mengetahui kekuatan, kelemahan yang dipengaruhi kebijakan internal perusahaan serta peluang dan ancaman yang dipengaruhi faktor-faktor eksternal yang tidak bisa dikontrol oleh perusahaan.

Faktor kekuatan, Yang dimaksud dengan faktor-faktor kekuatan yang dimiliki oleh suatu perusahaan adalah antara lain kompetensi khusus yang terdapat dalam organisasi yang berakibat pada pemilikan keunggulan komparatif oleh unit usaha di pasaran. Faktor kelemahan, Jika orang berbicara tentang kelemahan yang terdapat dalam tubuh suatu satuan bisnis, yang dimaksud ialah keterbatasan atau kekurangan dalam hal sumber, ketrampilan dan kemampuan yang menjadi penghalang serius bagi penampilan kinerja organisasi yang memuaskan. Faktor peluang, Definisi sederhana tentang peluang ialah sebagai situasi lingkungan yang menguntungkan bagi suatu satuan bisnis. Yang dimaksud dengan berbagai situasi tersebut antara lain ialah; Kecenderungan penting yang terjadi di kalangan penguna produk, identifikasi suatu segmen pasar yang belum mendapat perhatian, perubahan dalam kondisi persaingan, perubahan dalam peraturan perundangundangan yang membuka berbagai perubahan dalam kondisi persaingan, hubungan dengan para pembeli yang akrab dan hubungan dengan pemasok yang harmonis. Faktor ancaman, Pengertian ancaman merupakan kebalikan pengertian peluang. Dengan demikian dapat dikatakan bahwa ancaman adalah faktor-faktor 
lingkungan yang tidak menguntungkan suatu satuan bisnis.

Setelah faktor-faktor strategis telah diidentifikasi, kemudian disusun tabel IFAS (Internal Strategic Factor Analisys Summary) untuk mengidentifikasi faktor-faktor internal, dan EFAS (External Strategic Factor Analisys Summary) untuk mengidentifikasi faktor-faktor eksternal dimana dalam tabel tersebut terdapat beberapa faktor-faktor yang telah teridentifikasi akan diberi nilai pembobotan dan rating.

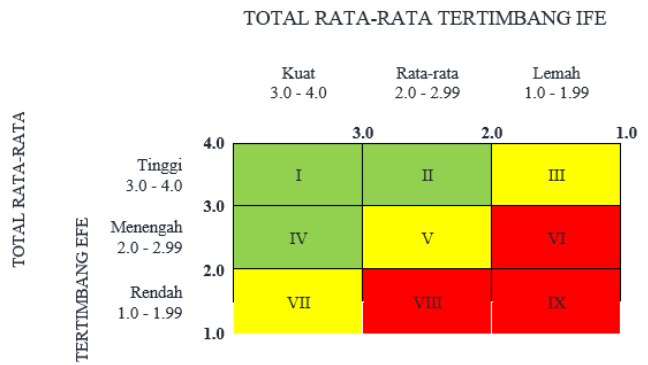

GAMBAR 1. MATRIX IFE - EFE

Gambar diatas menunjukkan bahwa situasi yang paling didambakan ialah sel 1 karena organisasi atau perusahaan menghadapi berbagai peluang lingkungan dan memiliki berbagai kekuatan yang mendorong pemanfaatan berbagai peluang tersebut. Dalam kondisi demikian, strategi yang tepat untuk ditempuh adalah strategi pertumbuhan. Sebaliknya, gambar 1 juga mnenunjukkan bahwa organisasi yang berada pada sel 4 menghadapi kondisi yang paling "buruk". Karena harus menghadapi tantangan besar yang bersumber pada lingkungan dan pada waktu yang bersamaan "dilanda" berbagai kelemahan internal yang kritikal sifatnya.

Strategi yang tepat dalam kondisi demikian adalah strategi yang bersifat defensif dalam arti mengurangi atau merubah bentuk keterlibatan perusahaan dalam produk atau pasar yang dianalisis mengunakan teknik SWOT. Pada sel 2 tergambar bahwa perusahaan yang memiliki berbagai kekuatan internal menghadapi situasi lingkungan yang tidak menguntungkan. Jika suatu perusahaan menemukan dirinya dalam kondisi demikian, strategi yang paling wajar untuk dipertimbangkan adalah strategi diversifikasi dalam arti suatu strategi yang memanfaatkan kekuatan yang dimilki sekarang untuk membuka peluang jangka panjang dengan produk atau pasar yang lain atau baru. Sel 3 pada diagram diatas menunjukkan posisi suatu perusahaan yang menghadapi peluang pasar yang besar disatu pihak akan tetapi "dihadang" oleh keterbatasan kemampuan karena berbagai kelemahan yang melekat dalam tubuh perusahaan tersebut. Dengan demikian, sangat wajar bagi perusahaan ini untuk "putar haluan" dalam arti mengambil berbagai langkah untuk mengatasi kelemahan yang dihadapi secara internal agar peluang pasar dapat dimanfaatkan.

\section{Hasil PEnelitian DAN PEMBahasan}

\section{A. Profil Hotel}

The Jayakarta Bandung Suite Hotel \& Spa merupakan induk Hotel pertama (pusatnya) yang didirikan di pusat pemerintahan Republik Indonesia yaitu di Kota Jakarta, yang mana asal mula nama Jakarta adalah Jayakarta. Diambilnya nama Jayakarta sebagai tanda penghargaan terhadap pendiri Kota Jakarta yaitu Pangeran Jayakarta. Hotel ini dibangun diatas tanah seluas $10.000 \mathrm{~m} 2$ dan dibuka pertama kali pada tanggal 10 Maret 1994. Kemudian selang setahun akhirnya diresmikan pula oleh Presiden Republik Indonesia Bapak Soeharto secara langsung yaitu pada tanggal 06 Desember 1995.

Hotel ini merupakan satu-satunya hotel bisnis dan resort bernuansakan Indonesia pada saat dibangun pertama kali di Jakarta, baik dari segi design interiornya maupun arsitektur bangunannya. Hotel ini merupakan tempat yang enak dan nyaman untuk beristirahat di akhir pekan bersama keluarga dan melakukan semua kegiatan bisnis bersama relasi kerja.

\section{B. Analisis Faktor Internal \& External}

Analisis lingkungan internal menghasilkan 6 faktor kekuatan dan 3 faktor kelemahan berdasarkan urutan yang di dapatkan dari pembobotan. Hasil selengkapnya bisa dilihat pada Tabel 1 dibawah ini.

TABEL 1. BOBOT, RATING DAN SKOR DARI INTERNAL FACTOR EVALUATION - IFE

\begin{tabular}{|c|c|c|c|c|}
\hline No & KEKUATAN & вовот & RATING & SKOR \\
\hline 1 & Beragamnya variasi menu yang ditawarkan & 0.12 & 3 & 0.36 \\
\hline 2 & Daya tarik menu yang ditawarkan & 0.11 & 4 & 0.44 \\
\hline 3 & $\begin{array}{l}\text { Suasana nyaman dan santai dalam menikmati } \\
\text { makanan, }\end{array}$ & 0.11 & 3 & 0.33 \\
\hline 4 & $\begin{array}{l}\text { Daya tarik keberagaman pengolahan } \\
\text { makanan }\end{array}$ & 0.13 & 2 & 0.26 \\
\hline 5 & $\begin{array}{l}\text { Keunikan cita rasa, aroma dan penyajian } \\
\text { makanan }\end{array}$ & 0.14 & 4 & 0.56 \\
\hline \multirow[t]{2}{*}{6} & $\begin{array}{l}\text { Sikap, penampilan, dan keramahan staf } \\
\text { restoran menyajikan makanan }\end{array}$ & 0.11 & 3 & 0.33 \\
\hline & \multicolumn{4}{|l|}{ KELEMAHAN } \\
\hline 1 & $\begin{array}{l}\text { Teknologi tradisional dalam pengolahan } \\
\text { makanan yang tidak optimal }\end{array}$ & 0.10 & 3 & 0.30 \\
\hline 2 & Promosi & 0.09 & 2 & 0.18 \\
\hline 3 & $\begin{array}{l}\text { Penguasaan bahasa asing dan hospitality skill } \\
\text { untuk wisatawan }\end{array}$ & 0.09 & 2 & 0.18 \\
\hline & TOTAL & 1.00 & & 2.94 \\
\hline
\end{tabular}

Sedangkan untuk analisis lingkungan external menghasilkan 6 faktor peluang dan 2 faktor ancaman berdasarkan urutan yang di dapatkan dari pembobotan. Hasil selengkapnya bisa dilihat pada Tabel 2 dibawah ini. 
TABEL 2. BOBOT, RATING DAN SKOR DARI EXTERNAL FACTOR EVALUATION - EFE

\begin{tabular}{|c|c|c|c|c|}
\hline No & PELUANG & вовот & RATING & SKOR \\
\hline 1 & $\begin{array}{l}\text { Adanya perintah dari pemerintah Kota bagi } \\
\text { tiap Hotel untuk menyajikan keaneka- } \\
\text { ragaman kuliner lokal }\end{array}$ & 0.14 & 3 & 0.42 \\
\hline 2 & $\begin{array}{l}\text { Branding kota Bandung sebagai kota tujuan } \\
\text { wisata kuliner }\end{array}$ & 0.13 & 3 & 0.39 \\
\hline 3 & $\begin{array}{l}\text { Berkembangnya wisata minat khusus (wisata } \\
\text { kuliner) }\end{array}$ & 0.12 & 3 & 0.36 \\
\hline 4 & $\begin{array}{l}\text { Berkembangnya ketertarikan wisatawan } \\
\text { terhadap makanan tradisional }\end{array}$ & 0.12 & 4 & 0.48 \\
\hline 5 & $\begin{array}{l}\text { Sedikitnya hotel bandung yang menyajikan } \\
\text { makanan autentik khas Sunda }\end{array}$ & 0.10 & 2 & 0.20 \\
\hline \multirow[t]{2}{*}{6} & $\begin{array}{l}\text { Akses Strategis menuju The Jayakarta } \\
\text { Bandung Suite Hotel \& Spa }\end{array}$ & 0.13 & 3 & 0.39 \\
\hline & \multicolumn{4}{|l|}{$\begin{array}{l}\text { ANCAMAN } \\
\end{array}$} \\
\hline 1 & Produk makanan dari daerah/negara lain & 0.14 & 3 & 0.42 \\
\hline 2 & $\begin{array}{l}\text { Ketatnya persaingan usaha jasa boga di kota } \\
\text { Bandung }\end{array}$ & 0.12 & 2 & 0.24 \\
\hline & TOTAL & 1.00 & & 2.90 \\
\hline
\end{tabular}

Berdasarkan hasil analisis faktor strategis lingkungan internal dan analisis faktor strategis lingkungan eksternal didapati nilai total skor faktor lingkungan internal sebesar 2,94. Melihat total skor faktor lingkungan internal yang diatas nilai rata-rata 2,50 menyimpulkan posisi internalnya kuat. Kemudian juga dari perolehan nilai total skor faktor eksternal sebesar 2,90 yang berada diatas nilai rata-rata 2,50 memposisikan juga faktor eksternalnya kuat. Gambar dibawah menunjukkan matriks posisi penjualan makanan tradisional sunda melalui daya tarik produk di The Jayakarta Bandung Hotel Suite \& Spa

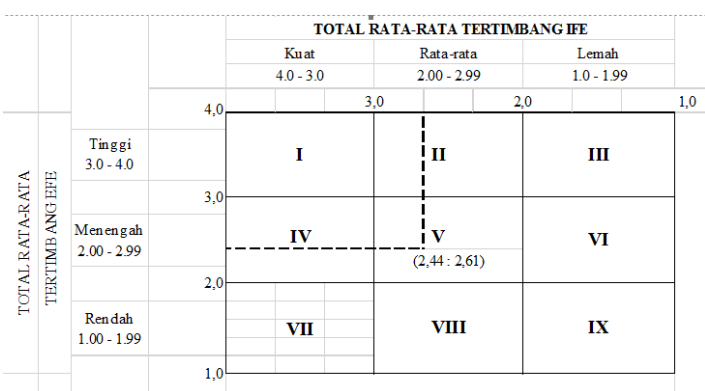

GAMBAR 2. MATRIKS INTERNAL-EKSTERNAL

Matriks Internal-Eksternal pada Gambar diatas menunjukkan posisi penjualan makanan tradisional sunda melalui daya tarik produk di The Jayakarta Bandung Hotel Suite \& Spa berada pada sel V. Karena itu, berdasarkan teori dari David (2006 : 302) maka strategi yang seharusnya diterapkan oleh The Jayakarta Bandung Hotel Suite \& Spa adalah "Hold and Maintain Strategy" atau strategi "Jaga dan Pertahankan" yang terdiri dari strategi penetrasi pasar dan strategi pengembangan produk. Strategi penetrasi pasar, yaitu usaha peningkatan pangsa pasar atau market share suatu produk atau jasa yang sudah ada di pasar melalui usaha pemasaran yang lebih gencar (David, 2006). Strategi berikutnya adalah strategi pengembangan produk. Strategi pengembangan produk merupakan salah satu cara dalam meningkatan kualitas pelayanan dengan cara meningkatkan mutu produk, memodifikasikan produk-produk atau jasa-jasa yang ada sekarang atau menambah jenis produk yang baru. Strategi pengembangan produk dilakukan untuk meningkatkan penjualan produk.

\section{Interpretasi Hasil}

\section{Strength - Opportunities (SO)}

Strategi yang memanfaatkan kekuatan untuk menggunakan peluang yang ada seperti :

1. Mengembangkan potensi daya tarik wisata dengan beragam jenis wisata kuliner, strategi ini dapat dilakukan dengan pengembangan program jenis wisata kuliner, seperti atraksi demo masak atau cooking class makanan masakan Sunda dan menjadi tuan rumah atas kompetisi atau event kuliner Sunda.

2. Mempertahankan keaslian dan kualitas produk makanan khas Sunda dengan diimplementasikan melalui kegiatankegiatan seperti membuat standar operasional dalam pengolahan makanan masakan Sunda atau Pemanfaatan teknologi tradisional dalam pemilihan metode memasak dan pemilihan alat memasak.

\section{Strength - Treathness (ST)}

Strategi menggunakan kekuatan dalam mengatasi ancaman, seperti:

1. Meningkatkan kualitas makanan tradisional khas Sunda melalui programprogram seperti tes makanan dan minuman serta memodifikasi produkproduk yang sudah ada.

2. Meningkatkan promosi makanan tradisional Sunda dimana promosi makanan tradisional Sunda dapat melakukan pengiklanan atau Personal selling.

\section{Weakness - Opportunities (WO)}

Strategi pemanfaatan peluang yang ada dengan cara mengatasi kelemahan seperti :

1. Membuat standard mutu dari produk makanan lokal khas Sunda, strategi ini dapat dilaksanakan melalui kegiatankegiatan seperti penerapan standar pembelian bahan dan membuat standar resep makanan masakan Sunda.

2. Melaksanakan pengawasan terhadap mutu produk makanan khas Sunda, yang dapat dilakukan melalui kegiatankegiatan seperti preparation-check 
sebelum makanan diolah juga melakukan final-check sebelum makanan dihidangkan.

Weakness - Threatness (WT)

Strategi ini ditunjukan untuk meminimalkan kelemahan serta menghindari ancaman yang didasarkan pada kegiatan yang bersifat bertahan (defensive), seperti:

1. Meningkatkan kualitas pelayanan, yang dapat dilakukan melalui kegiatan-kegiatan seperti melakukan traning (pelatihan) terhadap karyawan dan memberikan program rewards and punishment pada karyawan.

2. Meningkatkan penawaran produk makanan tradisional Sunda, yang dapat dilakukan melalui cara seperti membuat festival-festival makanan masakan Sunda atau membuat sebuah jamuan makan.

D. Pemilihan Prioritas Strategi dengan Quantitative Strategics Planning Matrix (QSPM)

Dalam menetapkan kemenarikan relatif (relative attractiveness) dari variasi strategistrategi yang telah dipilih, maka Analisis matriks QSPM bertujuan untuk menentukan strategi mana yang dianggap paling baik untuk dilakukan. Matriks SWOT menghasilkan strategi-strategi alternatif yaitu:

1. Mengembangkan potensi daya tarik wisata dengan beragam jenis wisata kuliner,

2. Mempertahankan keaslian dan kualitas produk makanan khas Sunda,

3. Meningkatkan kualitas makanan tradisional khas Sunda,

4. Meningkatkan promosi makanan tradisional Sunda,

5. Membuat standard mutu dari produk makanan lokal khas Sunda,

6. Melaksanakan pengawasan terhadap mutu produk makanan khas Sunda,

7. Memperbaiki kualitas pelayanan,

8. Meningkatkan penawaran produk makanan tradisional Sunda.

Strategi-strategi alternatif tersebut kemudian disusun dalam matriks QSPM sampai pada akhirnya ditemukan gambaran mengenai nilai TAS (Total Attractives Score). Hasilnya pada strategi meningkatkan penawaran produk makanan tradisional Sunda, dan meningkatkan promosi makanan tradisional Sunda, menunjukkan nilai tertinggi yang berarti bahwa strategi ini menjadi pilihan utama. Kemudian strategi mengembangkan potensi daya tarik wisata dengan beragam jenis wisata kuliner, dan memperbaiki kualitas pelayanan menjadi pilihan kedua. Lalu strategi meningkatkan kualitas makanan tradisional khas Sunda, dan mempertahankan keaslian juga kualitas produk makanan khas Sunda, menjadi pilihan ketiga. Serta strategi membuat standard mutu dari produk makanan lokal khas Sunda, dan melaksanakan pengawasan terhadap mutu produk makasnan khas Sunda menjadi pilihan terakhir.

\section{KESIMPULAN}

Dari penelitian mengenai strategi peningkatan penjualan makanan tradisional sunda melalui daya tarik wisata di The Jayakarta Bandung Suite Hotel \& Spa, beberapa kesimpulan yang dapat ditarik dari hasil penelitian adalah sebagai berikut:

1. Berdasarkan hasil penelitian yang dilakukan, dalam peningkatan penjualan masakan tradisional sundanya The Jayakarta Bandung Suite Hotel \& Spa memiliki kekuatan atau potensi sebagai daya tarik wisata kuliner di kota Bandung. Dimana potensi atau kekuatan yang dimiliki The Jayakarta Bandung Suite Hotel \& Spa sebagai daya tarik wisata kuliner di kota Bandung secara berurutan sebagai berikut: daya tarik menu yang ditawarkan, keunikan cita rasa, aroma dan penyajian makanan, penampilan, sikap dan keramahan staf restoran menyajikan makanan, beragamnya variasi menu yang ditawarkan, teknologi tradisional dalam pengolahan makanan, dan daya tarik keberagaman pengolahan makanan. Sedangkan, faktor kelemahannya secara berurutan antara lain berikut: manajemen operasional dapur yang tidak optimal, penguasaan bahasa asing dan hospitality skill untuk wisatawan, hygiene dan sanitasi. Dimana dalam pengembangannya berdasarkan total skor yang diteliti atas hasil evaluasi faktor internal yakni kekuatan/potensi internal dan kelemahan yang dimiliki oleh The Jayakarta Bandung Suite Hotel \& Spa mampu memanfaatkan faktor-faktor kekuatan yang ada untuk dapat mengatasi faktor-faktor kelemahannya. Sehingga The Jayakarta Bandung Suite Hotel \& Spa berpotensi dan mempunyai potensi yang kuat sebagai daya tarik wisata kuliner di kota Bandung.

2. Dari hasil analisis yang dilakukan peneliti berdasarkan observasi dan wawancara yang dilakukan atas pengembangan The Jayakarta Bandung Suite Hotel \& Spa, maka diperoleh beberapa peluang The Jayakarta Bandung 
Suite Hotel \& Spa sebagai daya tarik wisata kuliner di kota Bandung. Dimana dihasilkan sebuah peluang dari lingkungan eksternal atas daya tarik wisata kuliner di kota Bandung yang merupakan peluang secara berurutan sebagai berikut: branding kota Bandung sebagai kota tujuan wisata kuliner, berkembangnya wisata minat khusus (wisata kuliner), akses strategis menuju The Jayakarta Bandung Suite Hotel \& Spa, himbauan pemerintah untuk lebih memperkenalkan keaneka-ragaman kuliner lokal, berkembangnya ketertarikan wisatawan terhadap makanan tradisional, dan sedikitnya restoran/ rumah makan yang menyajikan makanan autentik khas Sunda. Sedangkan faktor ancamannya secara berurutan sebagai berikut: Produk makanan dari daerah/ negara lain dan ketatnya persaingan usaha jasa boga di kota Bandung. Dengan hasil analisis yang dilakukan dengan menggunakan matriks eksternal mampu memanfaatkan peluang dan menghindari ancaman. Sehingga The Jayakarta Bandung Suite Hotel \& Spa memiliki peluang yang cukup potensial untuk mengembangkan The Jayakarta Bandung Suite Hotel \& Spa sebagai daya tarik wisata kuliner di kota Bandung.

3. Strategi yang relevan untuk dilaksanakan dalam rangka mendukung pengembangan The Jayakarta Bandung Suite Hotel \& Spa sebagai daya tarik wisata kuliner di kota Bandung adalah:

4. Berdasarkan analisis matriks IE diperoleh strategi umum yang dapat dilaksanakan yaitu strategi penetrasi pasar dan strategi pengembangan produk. Strategi penetrasi pasar dilakukan dengan usaha peningkatan pangsa pasar atau market share produk makanan tradisional pada The Jayakarta Bandung Suite Hotel \& Spa yang sudah ada melalui usaha pemasaran yang lebih gencar. Sedangkan, strategi pengembangan produk dapat dilakukan dengan cara meningkatkan mutu produk, memodifikasikan produkproduk atau jasa-jasa yang ada sekarang atau menambah jenis produk yang baru. Strategi tersebut dapat dilakukan dengan menumbuhkan keyakinan bagi semua pihak, terutama pelaku usaha wisata yakni travel agent di kota Bandung untuk memberikan push factor (faktor pendorong) dengan membuat paket wisata kuliner dengan The Jayakarta Bandung Suite Hotel \& Spa dan juga pemerintah untuk mengenalkan bahwa potensi makanan tradisional Sunda amat sangat potensial untuk dikembangkan sehingga perlu intesifikasi pemasaran melalui promosi serta menambah variasi kegiatan wisata pada makanan tradisional Sunda sehingga wisatawan merasa ingin kembali mencicipi sajian kuliner Sunda.

5. Strategi alternatif yang relevan untuk dilaksanakan pada The Jayakarta Bandung Suite Hotel \& Spa sebagai daya tarik wisata kuliner di kota Bandung sebagai berikut: Strategi Strengths Opportunities (SO) adalah strategi yang menggunakan kekuatan untuk memanfaatkan peluang yang ada terdiri dari mengembangkan potensi daya tarik wisata dengan beragam jenis wisata kuliner, mempertahankan keaslian dan kualitas produk makanan khas Sunda. Strategi Strengths Threats (ST) adalah strategi yang menggunakan kekuatan untuk mengatasi ancaman terdiri dari meningkatkan kualitas makanan tradisional khas Sunda, meningkatkan promosi makanan tradisional Sunda. Strategi Weaknesses Opportunities (WO) adalah strategi meningkatkan peluang dengan menekan kelemahan yang dimiliki dengan membuat standard mutu dari produk makanan lokal khas Sunda, melaksanakan pengawasan terhadap mutu produk makanan khas Sunda. Strategi Weaknesses Threats (WT) adalah strategi memperbaiki kualitas pelayanan dan meningkatkan penawaran produk makanan tradisional Sunda.

\section{A. Saran}

Dari berbagai uraian tersebut di atas, merujuk pada kelemahan dan ancaman yang dimiliki dalam peningkatan penjualan makanan tradisional sunda di The Jayakarta Bandung Suite Hotel \& Spa melalui daya tarik wisata kuliner terdapat beberapa saran pada The Jayakarta Bandung Suite Hotel \& Spa seperti berikut.

1. Potensi dalam pengembangan wisata kuliner masih amat luas dan sangat kaya untuk dapat lebih dieksplorasi. Dimana minat wisatawan akan wisata kuliner pun dewasa ini semakin meningkat setiap tahun, khususnya di kota Bandung. Perkembangan wisata kuliner tersebut dapat dilihat dengan pertumbuhan pengusaha jasa boga yang terus meningkat. Hal ini dapat dimaknai baik ketika setiap kompetitor memiliki ragam diversifikasi produk sehingga konsumen / wisatawan yang berasal dari luar kota Bandung dapat dengan senang hati untuk terus datang kembali ke Bandung. Dalam hal ini, potensi yang dimiliki The Jayakarta Bandung Suite Hotel \& Spa dapat terus digali dengan menyajikan dan mengenalkan makananmakanan tradisional Sunda yang mulai sulit untuk ditemukan pada era globalisasi ini. Sesuai dengan konsep yang diusung oleh 
The Jayakarta Bandung Suite Hotel \& Spa yakni memberikan sebuah nilai dan daya tarik tersendiri pada konsumen yang berkunjung. Saat makanan tradisional Sunda tak lagi bersua karena maraknya makanan luar negeri yang semakin gencar menawarkan produknya, selayaknya hal tersebut dapat menjadi dorongan bagi The Jayakarta Bandung Suite Hotel \& Spa untuk dapat terus konsisten pada peningkatan penjualan makanan tradisional yang memberikan sebuah daya tarik bagi konsumen untuk dapat mengenal identitas kuliner Sunda.

2. Dalam perkembangannya, wisata kuliner memiliki beragam jenis wisata yang dapat ditingkatkan khususnya dalam hal menarik minat konsumen / wisatawan. Dimana wisatawan yang ingin berwisata kuliner seolah hanya dapat mengetahui rumah makan atau restoran saat ada kebutuhan untuk makan. Namun hal ini tentu tidak sejalan dengan perkembangan wisata kuliner dewasa ini, dimana kegiatan makan tidak hanya dimaknai dari rasa lapar saja. Kegiatan makan dewasa ini berkembang menjadi sebuah keinginan sehingga hal ini selayaknya dapat dimanfaatkan dan dioptimalkan oleh pelaku usaha perhotelan guna membuat push factor. Dimana manajemen hotel dapat bekerja sama dengan perencana kegiatan wisata seperti misalkan dengan travel agent sehingga kegiatan makan ini dapat didorong dengan perencanaan yang baik dan kedepan kegiatan wisata kuliner ini dapat terus berkembang tidak hanya pada restoran umum diluar hotel melainkan restoran di dalam hotel. Mengingat potensi wisata kuliner di kota Bandung sangat luar biasa yang didukung pula dengan peminatnya yang selalu meningkat.

\section{DAFTAR RUJUKAN}

Adimihardja, K. (2005). Makanan dalam Khazanah Budaya. Bandung: Disbudpar Propinsi Jawa Barat \& UPT Inrik Unpad.

Anonim. (tanpa tahun). Masakan Sunda. Melalui <https://id.wikipedia.org/wiki/ Masakan_Sunda> [12/26/15]

Anonim. (2014). Pengertian Peningkatan Menurut Para Ahli. Melalui <http:// www.duniapelajar.com/2014/08/08/pengerti an-peningkatan-menurut-para-ahli/> [02/07/16]

Anonim. (2014). Pengertian Hotel dan Definisi Hotel. Melalui $<$ http://jenishotel.info/pengertian-hotel $>$ [12/09/16]
Antara. (2014). Persaingan Hotel Kian Ketat. Melalui <http://kabar24.bisnis.com/ $\mathrm{read} / 20140811 / 78 / 249032 /$ kotabandungpers ainganhotelkianketat> [01/03/16].

Antariksa, Y. (2012). Strategi Penjualan dan Teknik Penjualan yang Efektif. Melalui <http://rajapresentasi.com/2012/03/strategipenjualan-dan-teknik-penjualan-yangefektif/> [12/09/16]

Arikunto, S. (2006). Prosedur Penelitian, Suatu Pendekatan Praktik. Jakarta: Rineka Cipta.

Basu Swastha, (2005), Manajemen Penjualan, Cetakan ke- dua belas, Yogyakarta : Liberty

Basu Swastha, (2001). Manajemen Pemasaran Modern; Yogyakarta: BPFE

Basu, S \& Irawan. (2008). Manajement Pemasaran Moderen. Yogyakarta : Liberty

Chairul Marom, (2002), Sistem Akuntansi Perusahaan Dagang, Edisi ke-dua,, Jakarta : Grasindo.

David, F. R. (2006). Strategic Management: Concepts. Terjemahan Ichsan Setiyo Budi. Jakarta: PT. Salemba Empat.

Ernayanti. (2003). Ensiklopedi Makanan Tradisional di Pulau Jawa dan Pulau Madura. Jakarta : Deputi Bidang Pelestarian dan Pengembangan Kebudayaan.

Hendrayana, M. (2011). Strategi Pengembangan Makanan Tradisional di Bali pada Hotel kawasan Sanur. Denpasar: Universitas Udayana

Henry Simamora, (2000), Akuntansi Basis Pengambilan Keputusan Bisnis, Jilid 1, Jakarta : Salemba Empat.

Herayati, D. Y., Masnia, D. N., \& Haryanti, D. T. (1986). Makanan: Wujud Variasi dan Fungsi Serta Cara Penyajiannya Pada Orang Sunda Daerah Jawa Barat. Bandung: Departemen Pendidikan dan Kebudayaan.

Hunger, D. K., \& Wheelen, T. L. (2003). Manajemen Strategis. Yogyakarta: Andi.

Kemendikbud. (tanpa tahun). Makanan Tradisional Provinsi Jawa Barat. Melalui $<$ http://petabudaya.belajar.kemdikbud.go.id /index8.php> [01/14/16]

Kuncoro, Mudrajat. (2006). Strategi: Bagaimana Meraih Keunggulan Bersaing. Jakarta : Erlangga.

Mertayasa, IGA. (2012). Food \& Beverage Service Operational : Job Preparation. Yogyakarta : ANDI. 
Nasir, M. (2005). Metodelogi Penelitian. Jakarta: Ghalia Indonesia.

Nilasari, S. (2014). Manajemen Strategi itu Gampang. Jakarta: Dunia Cerdas

Oka, A, Yoeti. (2002). Perencanaan Strategis Pemasaran Daerah Tujuan Wisata. Jakarta: Pradnya Paramita.

Oktama, IWAR. (2012). Pengertian Food \& Beverage Service. Melalui <http://ricooktama.blogspot.co.id/2012/09/p engertian-food-beverage-service.html> [12/09/16]

Pearce dan Robinson. (2000). Strategic Management Formulation, Implementation, and Control. 7th Edition. McGraw-Hill

Pendit, I Nyoman, S. (1994). Ilmu Pariwisata Sebuah Pengantar Perdana. Jakarta: Pradnya Paramita.

Rangkuti, F. (2006). Analisis SWOT: Teknik Membedah Kasus Bisnis-Reorientasi Konsep Perencanaan Strategis untuk Menghadapi Abad 21. Cetakan ke-14. Jakarta: Gramedia Pustaka Utama.
Rangkuti, F. (2009). Strategi Promosi yang Kreatif. Jakarta : Gramedia Pustaka Utama

Solihin, I. (2012). manajemen strategik. Jakarta: Erlangga.

Sugiyono. (2004). Metode Penelitian Bisnis. Bandung : CV. Alfabeta

Sugono, D (red). (2008). Kamus Bahasa Indonesia. Jakarta : Pusat Bahasa Departemen Pendidikan Nasional

Sumarni Murti dan Jhon Suprihanto. (2003). Bauran Pemasaran dan Loyalitas Pelanggan, Edisi Ketiga, Jilid I. Jakarta : Bumi Aksa.

Sumaryadi, \& Ganef. (2010). Kajian Wisata Kuliner Kota Bandung. Jurnal Kepariwisataan Indonesia, 473.

Tjiptono, F. (2011). Pemasaran Jasa. Malang : Bayu Media.

Widyaningsih, H. (2013). Partisipasi Hotel Menyajikan Makanan Tradisional Untuk Memperkenalkan Kuliner Yogyakarta. Jurnal Khasanah Ilmu. Vol.04 No.02 : 49-57 
